\title{
PENGEMBANGAN MODEL EVALUASI KEBIJAKAN KEGIATAN BELAJAR MEMBACA DI TAMAN KANAK-KANAK
}

Oleh: Rusijono

\begin{abstract}
Abstrak
Penelitian ini bertujuan mengembangkan model evaluasi kebijakan dan mengkaji implikasi model tersebut terhadap kebijakan kegiatan belajar membaca di Taman Kanak-kanak (TK). Model evaluasi yang dikembangkan mencakup evaluasi konteks, masukan, partisipasi, dan hasil (KMPH). Evaluasi konteks mencakup budaya baca keluarga, ketersediaan bahan bacaan untuk anak di rumah, dan kegiatan literasi keluarga bersama anak. Evaluasi masukan, partisipasi, dan hasil masingmasing terdiri atas satu variabel, yaitu: kesiapan membaca anak, aktivitas anak dalam kegiatan belajar membaca di TK, dan kemampuan membaca anak. Subjek penelitian ini adalah anak TK di Kabupaten Sidoarjo, Provinsi Jawa Timur. Metode pengumpulan data yang digunakan adalah angket, tes, dan observasi. Teknik analisis yang digunakan adalah model persamaan struktural. Hasil penelitian ini menunjukkan bahwa model KMPH didukung data sehingga dapat digunakan untuk mengevaluasi kebijakan kegiatan belajar membaca di TK.
\end{abstract}

Kata kunci: pengembangan model evaluasi kebijakan, belajar membaca di taman kanak-kanak 


\section{Pendahuluan}

Hurlock (1978: 30) mengatakan bahwa perkembangan awal anak (masa kanak-kanak) lebih kritis dibandingkan dengan perkembangan berikutnya, karena perkembangan berlangsung secara berkesinambungan. Hal ini berarti perkembangan suatu tahap akan berpengaruh terhadap perkembangan tahap berikutnya, dan pola kepribadian anak berkembang menjadi relatif tetap. Slavin (1994: 73) juga mengatakan hal yang sama, bahwa pada anak usia antara 3 dan 6 tahun terjadi perkembangan yang cepat pada semua aspek perkembangan.

Hasil penelitian La Paro dan Pianta (2000: 471) menyimpulkan bahwa kemampuan akademik dan sosial pada waktu anak di TK mempunyai korelasi yang positif dengan kemampuan akademik dan sosial ketika mereka berada di kelas 1 dan 2 Sekolah Dasar (SD). Penelitian lain menyimpulkan bahwa keterampilan literasi dan numerasi awal pada saat anak masuk TK mempunyai sumbangan positif terhadap kemampuan dan keterampilan membaca serta matematika anak pada saat di TK dan kelas 1 SD, yaitu setelah mereka belajar selama hampir satu tahun di TK dan di kelas 1 SD (Denton dan West, 2002: 7). Oleh karena itu, beberapa negara bagian di Amerika Serikat membuat peraturan bahwa pembelajaran membaca formal telah diberikan mulai anak belajar di TK (Heilman, Blair, dan Rupley, 1986: 80).

Kebijakan Departemen Pendidikan dan Kebudayaan (Depdikbud) melalui Program Kegiatan Belajar di Taman Kanak-kanak tahun 1994 (PKBTK 1994) tidak menganjurkan anak TK diberi pelajaran membaca dan menulis. Pada tahun 1999 Direktur Jenderal Pendidikan Dasar dan Menengah Departemen Pendidikan Nasional mengeluarkan Surat Edaran nomer 6205/C/DS/1999 tanggal 27 Juli 1999. Isi Surat Edaran tersebut menyatakan bahwa keterampilan dasar membaca, menulis dan berhitung dapat diberikan di TK secara terintegrasi dalam program pengembangan kemampuan dasar (Depdiknas, 2000: i).

Pada tahun 2002 Menteri Pendidikan Nasional Republik Indonesia mengeluarkan keputusan nomor 118/U/2002 tentang Penyesuaian GarisGaris Besar PKBTK yang isinya sama dengan PKBTK 1994 (Depdiknas, 
2002). Penyesuaian hanya dilakukan pada sistem yang digunakan, PKBTK 1994 menggunakan sistem caturwulan sedang PKBTK penyesuaian menggunakan sistem semester. Keputusan ini dapat dipahami sebagai penegasan kembali bahwa isi Garis-Garis Besar PKBTK 1994 masih berlaku.

Pada tahun 2004 Departemen Pendidikan Nasional (Depdiknas) mengeluarkan kurikulum TK 2004, walaupun tanpa surat keputusan menteri atau sejenisnya, kurikulum tersebut telah disosialisasikan secara luas. Kurikulum tersebut menyatakan bahwa kompetensi dasar berbahasa yang ingin dicapai anak TK kelompok B adalah mampu mendengarkan, berkomunikasi secara lisan, memiliki perbendaharaan kata dan mengenal simbol-simbol yang melambangkannya untuk persiapan membaca dan menulis (Depdiknas, 2004: 13).

Ketidaksesuaian antara kebijakan Depdiknas yang tertuang dalam PKBTK 1994, Surat Edaran nomer 6205/C/DS/1999, Garis-Garis Besar PKBTK penyesuaian tahun 2002, dan Kurikulum TK 2004 dapat dipahami sebagai ketidakjelasan konsep yang mendasari berbagai kebijakan yang diambil lembaga di lingkungan Depdiknas tersebut. Hal ini menunjukkan pentingnya dilakukan evaluasi yang mendalam tentang kebijakan kegiatan belajar membaca di TK, khususnya konsep yang mendasari kebijakan tersebut. Mengingat model yang tepat untuk mengevaluasi kebijakan kegiatan belajar membaca di TK belum tersedia, maka pegembangan model evaluasi kebijakan kegiatan belajar membaca di TK dinilai sangat mendesak.

Bodrova, Deborah, dan Paynter (1999: 2) menyatakan bahwa salah satu issue (persoalan) yang perlu diperhatikan berkaitan dengan konsep pendidikan yang sesuai dengan perkembangan anak adalah pendapat yang mengatakan bahwa mengajarkan materi atau keterampilan tertentu pada anak kecil sangat berbahaya bagi anak, karena hal tersebut sama dengan mempercepat perkembangan anak yang dapat merusak kemampuan belajar anak pada waktu yang akan datang. Pendapat ini menunjukkan betapa pentingnya memperhatikan faktor perkembangan sebagai dasar untuk menyusun standar literasi bagi anak prasekolah. 
Slavin (1994: 76) mengatakan bahwa anak usia 3 tahun sudah dapat membedakan tulisan dan lukisan. Anak prasekolah sudah banyak yang dapat membaca buku dari awal sampai akhir dengan menafsirkan gambar pada setiap halaman, dapat memahami alur cerita dan dapat memprediksi apa yang akan terjadi berikutnya pada cerita sederhana, serta dapat membaca logo tertentu. Penelitian Chandler (2000: 2) menyimpulkan bahwa sebagian besar anak usia 4 tahun sudah menunjukkan keterampilan motorik halus dan munculnya tanda-tanda literasi. Teale dan Sulzby (Ramsburg, 1998: 2) menyimpulkan bahwa perkembangan literasi mulai sebelum anak masuk sekolah. Mereka memberikan contoh bahwa anak usia 2 atau 3 tahun sudah mengenal tanda, label, atau logo yang sering mereka lihat.

Heilman, Blair, dan Rupley (1986: 90) mengatakan bahwa penilaian terhadap kesiapan membaca anak sangat menentukan keberhasilan atau kegagalan program pembelajaran membaca, artinya penilaian yang tepat terhadap kesiapan membaca anak merupakan langkah awal yang tepat untuk memberikan program pembelajaran membaca kepada anak. Program pembelajaran membaca yang tepat (sesuai dengan perkembangan anak) akan memberikan hasil yang optimal. Havighurst menyebut keadaan saat anak sudah siap melakukan suatu kegiatan dengan istilah teachable moment (Hurlock, 1978: 8). Lebih lanjut juga dinyatakan bahwa teachable moment tidak terjadi bersama-sama untuk semua pola tingkah laku, semua keadaan, dan semua anak.

Beberapa hasil penelitian mutakhir di berbagai negara yang dikaji Fisher (1998: 8) menyimpulkan bahwa literacy development (perkembangan literasi) atau yang sering disebut reading readiness or emengent literacy (kesiapan membaca) sudah mulai tumbuh sebelum anak masuk TK. Kajian ini juga menyimpulkan bahwa keluarga mempunyai pengaruh besar terhadap kesiapan membaca anak karena pengaruh keluarga terhadap pendidikan anak sebelum masuk TK cukup besar. Hasil kajian ini didukung hasil penelitian Nord dkk., (2000: 2) yang menyimpulkan bahwa kegiatan literasi keluarga bersama anak berpengaruh terhadap kesiapan membaca anak. Berdasarkan hasil penelitian ini, kesiapan membaca anak dari suatu 
keluarga atau etnik tidak dapat dijadikan ukuran/kriteria bagi kesiapan membaca anak dari keluarga atau etnik lain.

Setiap keluarga atau etnik mempunyai budaya dan karakteristik yang berbeda-beda sehingga kesiapan membaca anak usia tertentu dari suatu keluarga atau etnik berbeda dengan kesiapan membaca anak sebaya dari keluarga atau etnik lain. Mengenai karakteristik keluarga yang mempunyai pengaruh terhadap kesiapan membaca anak dijelaskan secara spesifik oleh hasil penelitian yang dilakukan White dan Dewitz (1996: 1) bahwa salah satu faktor keluarga yang mempengaruhi perkembangan literasi adalah ketersediaan bahan bacaan di rumah. Karena kesiapan membaca anak merupakan salah satu tahap dari perkembangan literasi maka diduga ketersediaan bahan bacaan di rumah juga berpengaruh terhadap kesiapan membaca anak. Sementara itu, Heilman, Blair, dan Rupley (1986: 85-89) mengatakan bahwa budaya mempengaruhi kesiapan membaca anak. Karena sebagian besar kehidupan anak berada di lingkungan keluarga, budaya yang mempunyai pengaruh besar terhadap kesiapan membaca anak adalah budaya keluarga, khususnya budaya yang berkaitan dengan kegiatan membaca dan menulis, yaitu budaya baca keluarga.

Berdasarkan hasil penelitian Nord dkk., (2000: 2), White dan Dewitz (1996: 1), Heilman, Blair, dan Rupley (1986: 85-89) dapat dinyatakan bahwa faktor yang mempengaruhi kesiapan membaca anak adalah: budaya baca keluarga, ketersediaan bahan bacaan untuk anak di rumah, dan kegiatan literasi keluarga bersama anak. Ketiga sumber ini diterbitkan di negara-negara barat dan diduga penelitian yang dilakukan tidak mengambil sampel di Indonesia. Mengingat setiap keluarga atau etnik mempunyai budaya dan karakteristik yang berbeda-beda, masalah ini menarik untuk dikaji secara empiris di Indonesia.

Masalah lain yang perlu dikaji adalah kesiapan membaca anak TK itu sendiri. Tersedianya data kesiapan membaca anak TK dinilai sangat penting karena dalam menetapkan kebijakan kegiatan belajar membaca di TK perlu memperhatikan hal tersebut. Kalau anak sudah siap belajar membaca tetapi tidak mendapat respons atau diberikan kegiatan sesuai dengan perkembangannya maka minat anak untuk belajar membaca akan hilang. Sebaliknya, kalau anak belum siap membaca dan dipaksa mengikuti 
kegiatan belajar membaca maka anak menjadi tertekan atau merasa terbebani oleh kegiatan yang tidak/belum sesuai dengan minat dan perkembangannya. Hal ini dikhawatirkan akan merugikan perkembangan anak selanjutnya dalam belajar membaca atau aspek perkembangan yang lain. Pendapat yang hampir sama dikemukakan oleh Hurlock (1978: 9) bahwa memberikan pelajaran membaca bagi anak yang belum siap hanya membuang-buang waktu saja. Usaha ini akan menumbuhkan perilaku yang tidak diinginkan dan merugikan perkembangan anak, seperti tidak ingin belajar atau belajar dengan tujuan agar tidak dimarahi oleh guru atau orang tua. Memperhatikan pendapat ini, dalam mengkaji kesiapan membaca anak perlu dikaitkan dengan aktivitas belajar dan hasil belajar yang diperoleh anak.

Uraian di atas menunjukkan pentingnya melakukan evaluasi terhadap kebijakan kegiatan belajar membaca di TK dan mengembangkan model yang tepat untuk melaksanakan evaluasi terhadap kebijakan tersebut serta mengkaji implikasi model tersebut terhadap kebijakan kegiatan belajar membaca di TK. Permasalahan dalam evaluasi ini dirumuskan sebagai berikut.

1. Bagaimanakah model evaluasi yang tepat untuk mengevaluasi kebijakan kegiatan belajar membaca di TK?

2. Bagaimanakah implikasi model evaluasi kebijakan kegiatan belajar membaca di TK terhadap kebijakan kegiatan belajar membaca di TK?

Kesiapan membaca menggambarkan perkembangan literasi pada anak kecil, sebelum anak berusia 5 atau 6 tahun, ketika mereka mulai membaca dan menulis. Kesiapan membaca tidak terjadi pada waktu tertentu, tetapi merupakan proses yang berkembang melalui perpaduan antara perkembangan dan pengalaman.

Kesiapan membaca ada pada diri anak dan bersifat internal sehingga orang lain tidak dapat mengetahui kecuali dari tanda-tandanya. Tandatanda bahwa anak telah siap belajar membaca dapat dikelompokkan menjadi dua hal. Pertama, tanda-tanda kesiapan membaca yang berkaitan dengan kemampuan anak, mencakup: kemampuan mengenal konsep dasar tulisan (mengenal bagian depan - belakang dan atas - bawah buku, membedakan tulisan dan gambar, mengetahui bahwa tulisan disusun dari 
kiri ke kanan, dari atas ke bawah), membedakan suara (bunyi bahasa), gambar, dan perpaduan antara bunyi bahasa dan gambar, mengenal huruf, mengenal kata, dan memahami bahasa lisan.

Kedua, tanda-tanda kesiapan membaca yang berkaitan dengan kebiasaan perilaku anak, antara lain mencakup: anak mulai tertarik pada buku, anak gemar membuka-buka buku, anak pura-pura membaca, anak mampu mengucapkan kata atau kalimat yang berkaitan dengan gambar yang dilihat, anak melihat gambar dengan berpura-pura membaca, anak sudah minta dibacakan buku atau cerita, anak dapat menceritakan gambar yang dibuatnya, anak ikut serta orang tua atau orang lain ketika sedang membaca surat kabar, majalah, atau buku lainnya, anak membaca hal-hal yang dilihatnya dalam perjalanan, anak mulai mengeja tulisan yang dijumpai, di majalah, surat kabar, atau yang lain, anak mulai senang mengajak orang tua ke tempat penjualan majalah, koran, atau buku, dan anak mulai bertanya tentang arti dan maksud suatu gambar.

Gillet dan Temple (1994: 14) mengatakan bahwa kesiapan membaca merupakan salah satu tahapan dari perkembangan literasi atau proses belajar membaca. Oleh karena itu, faktor-faktor yang mempengaruhi perkembangan literasi juga berpengaruh terhadap kesiapan membaca anak. White dan Dewitz (1996: 1-2) menyebutkan faktor keluarga (bome) yang mendukung perkembangan literasi ada 4 macam, yaitu: ketersediaan bahan bacaan di rumah (literacy materials in the bome), membaca santai (reading for fun), mendiskusikan masalah literasi dengan keluarga (literacy discussions with family), kebiasaan melihat televisi (television viewing habits). Kegiatan membaca santai pada umumnya belum dapat dilakukan oleh anak TK. Karena itu, pengaruh faktor ini terhadap kesiapan membaca anak TK dapat diabaikan. Penelitian yang dilakukan Fisher (1988: 29) menyimpulkan bahwa ketersediaan bahan bacaan mempunyai pengaruh terhadap keinginan anak untuk belajar membaca. Sementara itu, Mountain (1981: 9) mengatakan bahwa cara terbaik untuk meningkatkan kesiapan membaca anak adalah bicara dengan anak dan membaca untuk anak.

Hasil penelitian Nord dkk. (2000: 2) menyimpulkan bahwa keluarga yang melakukan kegiatan literasi (literacy activities) dengan melibatkan anak dapat meningkatkan kesiapan membaca anak. Lebih lanjut diuraikan bahwa 
kegiatan literasi keluarga bersama anak meliputi: membaca untuk anak, bercerita untuk anak, bernyanyi untuk anak, mengajak anak ke tempattempat yang banyak tersedia buku-buku terutama buku yang sesuai dengan anak, mengajarkan huruf, kata, serta angka.

Sejalan dengan hasil penelitian di atas, Masyhor (1997: 11) mengatakan bahwa orang tua mempunyai peran yang besar dalam proses pembudayaan (enculturation) suatu nilai, sikap, atau perbuatan. Orang tua yang mempunyai kebiasaan atau budaya membaca yang tinggi, maka budaya membaca tersebut akan menurun kepada anak-anaknya dan mereka akan tumbuh menjadi anak-anak yang suka membaca. Anak yang suka membaca tentu akan senang dan memperhatikan tulisan, buku, atau hal-hal yang terkait dengan tulisan. Hal ini akan berpengaruh terhadap kesiapan membaca anak.

Dari berbagai pendapat dan hasil penelitian yang telah diuraikan dapat disimpulkan bahwa faktor-faktor yang mempengaruhi kesiapan membaca anak adalah: budaya baca keluarga, ketersediaan bahan bacaan untuk anak di rumah, dan kegiatan literasi keluarga bersama anak.

Kajian evaluasi kebijakan ini mencakup empat komponen, yaitu: kondisi keluarga, tingkat kesiapan membaca anak, aktivitas anak dalam kegiatan belajar membaca, dan kemampuan membaca anak. Komponen yang dikaji dalam evaluasi kebijakan ini hampir sama dengan model CIPP dan CIRO. Berdasarkan pada kedua model tersebut, maka kondisi keluarga termasuk dalam cakupan evaluasi konteks dan kesiapan membaca anak termasuk dalam cakupan evaluasi masukan. Menurut model CIPP, aktivitas anak dalam kegiatan belajar membaca termasuk dalam evaluasi proses, sedangkan menurut model CIRO termasuk dalam evaluasi reaksi peserta terhadap pelaksanaan program. Dengan pertimbangan bahwa kegiatan belajar membaca di TK merupakan rencana dari guru atau pihak di luar anak dengan mempertimbangkan tingkat perkembangan anak dan bukan atas kesepakatan dengan anak, maka aktivitas anak dalam kegiatan belajar membaca lebih dekat dianggap sebagai reaksi anak terhadap kegiatan belajar membaca di TK.

Ditinjau dari teori pembelajaran, penggunaan istilah reaksi terhadap aktivitas anak dalam kegiatan belajar dinilai kurang tepat karena anak 
merupakan pusat dalam proses kegiatan belajar. Semua aktivitas yang dilakukan guru dalam kegiatan ini diharapkan dapat membelajarkan anak. Oleh karena itu, dalam merancang kegiatan belajar di TK, guru hendaknya selalu memperhatikan perkembangan anak. $\mathrm{Hal}$ ini bertujuan agar kegiatan belajar yang diberikan sesuai dengan tingkat perkembangan anak sehingga anak tertarik dan mampu melibatkan diri secara aktif, baik fisik maupun psikis. Dengan keterlibatan tersebut diharapkan terjadi proses belajar pada diri anak. Berdasarkan uraian ini maka aktivitas anak dalam kegiatan belajar lebih tepat disebut dengan partisipasi anak dalam kegiatan belajar.

Kemampuan membaca anak merupakan hasil dari kegiatan belajar membaca. Kalau mengacu pada model CIPP maka komponen ini termasuk dalam evaluasi hasil (product), sedangkan kalau mengacu pada model CIRO maka kemampuan membaca anak termasuk dalam evaluasi outcome atau lebih spesifik termasuk dalam immediate outcomes. Sesuai dengan pembatasan masalah yang diuraikan pada bab I, maka intermediate outcomes dan ultimate outcomes tidak dikaji dalam evaluasi ini. Oleh karena itu, kemampuan membaca anak lebih tepat disebut dengan konsep evaluasi hasil.

Berdasarkan kajian tentang cakupan evaluasi kebijakan di atas, maka model evaluasi yang tepat untuk evaluasi kebijakan kegiatan belajar membaca di TK adalah model KMPH (Konteks, Masukan, Partisipasi, Hasil). Model ini merupakan perpaduan antara CIPP dan CIRO, yang disesuaikan dengan karakteristik kebijakan kegiatan belajar di TK, yaitu selalu memperhatikan tingkat perkembangan anak, khususnya kesiapan membaca anak.

Sesuai dengan kajian teori yang telah diuraikan, evaluasi konteks mencakup: budaya baca keluarga, ketersediaan bahan bacaan untuk anak di rumah, dan kegiatan literasi keluarga bersama anak. Evaluasi masukan, partisipasi, dan hasil masing-masing terdiri atas satu variabel, yaitu: kesiapan membaca anak, aktivitas anak dalam kegiatan belajar membaca, dan kemampuan membaca anak. 


\section{Hipotesis}

Hipotesis penelitian ini adalah model evaluasi KMPH tepat untuk mengevaluasi kebijakan kegiatan belajar membaca di TK. Bentuk hubungan antarvariabel dalam model evaluasi ini sebagai berikut.

1. Budaya baca keluarga, ketersediaan bahan bacaan untuk anak di rumah, dan kegiatan literasi keluarga bersama anak mempunyai pengaruh yang signifikan terhadap kesiapan membaca anak.

2. Budaya baca keluarga, ketersediaan bahan bacaan untuk anak di rumah, dan kegiatan literasi keluarga bersama anak mempunyai pengaruh keseluruhan dan pengaruh langsung yang signifikan terhadap aktivitas anak dalam kegiatan belajar membaca di TK.

3. Budaya baca keluarga, ketersediaan bahan bacaan untuk anak di rumah, dan kegiatan literasi keluarga bersama anak mempunyai pengaruh keseluruhan dan pengaruh langsung yang signifikan terhadap kemampuan membaca anak.

4. Kesiapan membaca anak mempunyai pengaruh keseluruhan dan pengaruh langsung yang signifikan terhadap kemampuan membaca anak.

5. Aktivitas anak dalam kegiatan belajar membaca di TK mempunyai pengaruh yang signifikan terhadap kemampuan membaca anak.

\section{Metode Penelitian}

Subjek penelitian ini adalah anak TK di Kabupaten Sidoarjo yang berjumlah 621 anak. Teknik multistage cluster random digunakan untuk menentukan subjek penelitian tersebut. Teknik pengumpulan data yang digunakan adalah: angket, tes, dan observasi. Angket digunakan untuk mengungkap data tentang budaya baca keluarga, ketersediaan bahan bacaan di rumah, kegiatan literasi keluarga bersama anak, dan kesiapan membaca anak. Observasi digunakan untuk mengumpulkan data tentang aktivitas anak dalam kegiatan belajar membaca. Tes digunakan untuk mengumpulkan data tentang kesiapan membaca dan kemampuan membaca anak. Kesiapan membaca anak diungkap menggunakan angket dan tes. Adapun teknik analisis data yang digunakan adalah model persamaan 
struktural menggunakan bantuan software Linear Structural Relationship (LISREL).

\section{Hasil Penelitian}

1. Kesesuaian Model Evaluasi Kebijakan Kegiatan Belajar Membaca di TK dengan Data Empirik

Kriteria yang digunakan untuk menguji kesesuaian model evaluasi kebijakan dan bentuk hubungan antarvariabel ada 3 macam, yaitu: $\chi^{2}$ (ChiSquare), Goodness of Fit Index (GFI), dan Root Mean Square Residual (RMR). Nilai $\chi^{2}$ hasil analisis terhadap model evaluasi kebijakan dan bentuk hubungan antarvariabel dalam model tersebut adalah $28 \cdot 20(p=0,659)$. Menggunakan taraf signifikansi 0.05 , hasil ini menunjukkan bahwa secara keseluruhan model evaluasi kebijakan kegiatan belajar membaca di TK didukung data.

GFI dari analisis ini termasuk kategori sangat tinggi, yaitu 0.992 . Hal ini berarti tingkat kesesuaian model evaluasi kebijakan kegiatan belajar membaca di TK dan bentuk hubungan antarvariabel di dalamnya dengan data terbukti sangat tinggi. Adapun nilai RMR yang diperoleh cukup kecil, yaitu 0.017. Nilai RMR yang kecil menunjukkan bahwa nilai residu dari model yang dikembangkan dalam menjelaskan data kecil. Berdasarkan ketiga kriteria tersebut, model evaluasi kebijakan kegiatan belajar membaca di TK mempunyai tingkat kesesuaian yang tinggi dengan data dan mampu menjelaskan data dengan residu yang kecil.

2. Validitas Konstruk

Nilai lambda variabel teramati dari variabel laten eksogen pada model evaluasi kegiatan belajar membaca di TK disajikan pada Tabel 1. Tabel tersebut menunjukkan bahwa semua faktor variabel laten eksogen mempunyai nilai lambda yang tinggi $(\geq 1,96)$. Variabel laten budaya baca keluarga mempunyai tiga faktor, yaitu: kebiasaan membaca ayah, ibu, dan anak. Pada analisis ini, faktor yang dianggap paling dominan adalah faktor kebiasaan membaca anak, sehingga nilai lambda faktor ini ditentukan 1.00 (fixed). 
Tabel 1

Nilai Lambda Variabel Laten Eksogen

\begin{tabular}{|c|c|c|c|}
\hline Faluer & $\begin{array}{c}\text { Budaya bsea } \\
\text { Rehuerga } \\
\left(\begin{array}{c}\vdots \\
\text { SE } \\
i\end{array}\right)\end{array}$ & $\begin{array}{c}\text { Reters adins Bshan } \\
\text { Bacan di Rumhth } \\
\left(\begin{array}{c}\text { SE } \\
1\end{array}\right)\end{array}$ & $\begin{array}{c}\text { Rogiatan Literasi Rol } \\
\text { beamana Anst } \\
\left(\begin{array}{c}1 \\
\text { SE } \\
1\end{array}\right)\end{array}$ \\
\hline 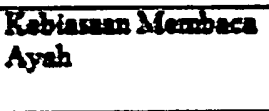 & $\begin{array}{c}0.563 \\
0.087 \\
11.104\end{array}$ & $\cdots$ & $\ldots$ \\
\hline $\begin{array}{l}\text { Koblasand Kenbeen } \\
\text { Ibo }\end{array}$ & $\begin{array}{r}0.994 \\
0.088 \\
11338 \\
\end{array}$ & $\cdots$ & $\cdots$ \\
\hline $\begin{array}{l}\text { Kobiasin Xembeca } \\
\text { Angl }\end{array}$ & 1.000 & $\cdots$ & $\cdots$ \\
\hline Jesis Bacan & $\cdots$ & $\begin{array}{c}0.95: \\
0.093 \\
10.332\end{array}$ & $\cdots$ \\
\hline Jumlah Bactan & 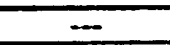 & 1.000 & $\cdots$ \\
\hline Eecen Dibeli 3 BIn & $\cdots$ & $\begin{array}{l}0.862 \\
0.090 \\
9.623 \\
\end{array}$ & $\cdots$ \\
\hline 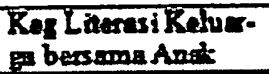 & $\cdots$ & $\cdots$ & 1.000 \\
\hline
\end{tabular}

Variabel laten ketersediaan bahan bacaan untuk anak di rumah mempunyai tiga faktor, yaitu: jenis bahan bacaan, jumlah bahan bacaan, dan jumlah bahan bacaan yang dibeli 3 bulan terakhir. Pada analisis ini, faktor yang dianggap paling dominan adalah jumlah bahan bacaan yang tersedia, sehingga nilai lambda faktor ini ditentukan 1.00 (fixed). Analisis menggunakan data baku menunjukkan hasil sama, nilai lambda yang paling tinggi adalah jumlah bahan bacaan yang tersedia dengan koefisien lambda 0.606 , kemudian diikuti oleh faktor jenis bahan bacaan dengan nilai lambda 0.580 dan faktor jumlah bahan bacaan yang dibeli dalam 3 bulan terakhir dengan nilai lambda 0.522 . Adapun variabel laten kegiatan literasi keluarga bersama anak hanya mempunyai satu faktor, sehingga nilai lambda faktor ini ditentukan 1.00 (fixed). 
Nilai lambda variabel teramati dari variabel laten indogen menunjukkan bahwa semua faktor dari variabel laten indogen mempunyai nilai lambda yang tinggi. Tingginya nilai lambda tersebut ditunjukkan dengan nilai t masing-masing faktor yang lebih besar dari 1,96. Variabel laten kesiapan membaca anak mempunyai dua faktor, yaitu: tanda-tanda kesiapan membaca anak yang berkaitan dengan kemampuan dan tandatanda kesiapan membaca anak yang berkaitan dengan perilaku. Pada analisis ini faktor yang dianggap lebih dominan adalah tanda-tanda kesiapan membaca anak yang berkaitan dengan kemampuan, sehingga nilai lambda faktor ini ditentukan 1.00 (fixed). Variabel aktivitas anak dalam kegiatan belajar membaca dan kemampuan membaca masing-masing hanya mempunyai satu variabel teramati. Oleh karena itu, dalam analisis keduanya ditentukan 1.00 (fixed).

\section{Pengaruh Variabel Laten Eksogen terhadap Variabel Laten Indogen}

Analisis model persamaan struktural pada penelitian ini mencakup 3 variabel laten eksogen dan 3 variabel laten indogen. Analisis model persamaan struktural menghasilkan tiga macam effect (pengaruh), yaitu: total effects (pengaruh keseluruhan) dan indirect effect (pengaruh tidak langsung) dan direct effect (pengaruh lansung). Pengaruh keseluruhan variabel laten eksogen terhadap variabel laten indogen disajikan pada Tabel 2. 
Tabel 2

Pengaruh Keseluruhan Variabel Laten Eksogen terhadap Variabel Laten Indogen

\begin{tabular}{|c|c|c|c|}
\hline & $\begin{array}{l}\text { Bud Membaca } \mathrm{Kal} \\
\left(\begin{array}{c}7 \\
\mathrm{SE} \\
\mathrm{t}\end{array}\right)\end{array}$ & $\begin{array}{c}\text { Bahan Bacann } \\
\left(\begin{array}{c}\eta \\
\text { SE } \\
t\end{array}\right)\end{array}$ & $\begin{array}{c}\text { Keg Literasi Kel } \\
\left(\begin{array}{c}\eta \\
\text { SE } \\
t\end{array}\right)\end{array}$ \\
\hline $\begin{array}{l}\text { Kesiapan } \\
\text { Mlembaca }\end{array}$ & $\begin{array}{l}0.482 \\
0.129 \\
3.727 \\
\end{array}$ & $\begin{array}{l}0.436 \\
0.136 \\
3.198 \\
\end{array}$ & $\begin{array}{l}0.078 \\
0.033 \\
2.382 \\
\end{array}$ \\
\hline Altivitas Angle & $\begin{array}{l}0.546 \\
0.162 \\
3.372 \\
\end{array}$ & $\begin{array}{l}0.499 \\
0.171 \\
2.911 \\
\end{array}$ & $\begin{array}{l}0.012 \\
0.042 \\
0.299 \\
\end{array}$ \\
\hline $\begin{array}{l}\text { Kemang } \\
\text { Mfembaca }\end{array}$ & $\begin{array}{l}0.436 \\
0.164 \\
2.655\end{array}$ & $\begin{array}{l}0.535 \\
0.176 \\
3.033 \\
\end{array}$ & $\begin{array}{l}0.004 \\
0.043 \\
0.098\end{array}$ \\
\hline
\end{tabular}

Tabel 2 menunjukkan bahwa budaya baca keluarga mempunyai pengaruh keseluruhan yang signifikan terhadap kesiapan membaca anak $(\gamma$ $=0.428 ; \mathrm{t}=3.727)$, aktivitas anak dalam kegiatan belajar membaca di TK $(\gamma=0.546 ; \mathrm{t}=3.372)$, dan kemampuan membaca anak $(\gamma=0.436 ; \mathrm{t}=$ 2.655). Ketersediaan bahan bacaan untuk anak di rumah juga mempunyai pengaruh keseluruhan yang signifikan terhadap kesiapan membaca anak $(\gamma$ $=0.436 ; \mathrm{t}=3.198)$, aktivitas anak dalam kegiatan belajar membaca di TK $(\gamma=0.499 ; \mathrm{t}=2.911)$, dan kemampuan membaca anak $(\gamma=0.535 ; \mathrm{t}=$ 3.033). Sebaliknya kegiatan literasi keluarga bersama anak hanya mempunyai pengaruh keseluruhan yang signifikan terhadap kesiapan membaca anak $(\gamma=0.078 ; t=2.382)$, sedang pengaruhnya terhadap aktivitas anak dalam kegiatan belajar membaca di TK dan kemampuan membaca anak terbukti tidak signifikan.

Hasil analisis pengaruh langsung variabel laten eksogen terhadap variabel laten indogen menunjukkan bahwa ketiga variabel laten eksogen mempunyai pengaruh langsung yang signifikan terhadap kesiapan membaca, sedangkan pengaruhnya terhadap aktivitas anak dalam kegiatan 
belajar membaca dan kemampuan membaca terbukti tidak signifikan. Hal ini menunjukkan pentingnya peran kesiapan membaca, karena sebagian besar pengaruh dari ketiga variabel eksogen terhadap aktivitas anak dalam kegiatan belajar membaca dan kemampuan membaca melalui kesiapan membaca anak.

\section{Pengaruh Variabel Laten Indogen terhadap Variabel Laten Indogen}

Hasil analisis menunjukkan bahwa kesiapan membaca anak mempunyai pengaruh keseluruhan yang signifikan terhadap aktivitas anak dalam kegiatan belajar membaca di TK $(\beta=1.126 ; t=2.114)$ dan kemampuan membaca anak $(\beta=1.617 ; t=2.270)$. Antara kesiapan membaca dan aktivitas anak dalam kegiatan belajar membaca tidak terdapat variabel antara, sehingga pengaruh keseluruhan tersebut sekaligus merupakan pengaruh langsung. Kesiapan membaca juga mempunyai pengaruh tidak langsung yang signifikan terhadap kemampuan membaca $(\beta$ $=0.256 ; t=3.447$ ). Namun, pengaruh langsung kesiapan membaca terhadap kemampuan membaca anak terbukti tidak signifikan $(t=1.944)$. Aktivitas anak dalam kegiatan belajar membaca juga mempunyai pengaruh keseluruhan dan sekaligus merupakan pengaruh langsung yang signifikan terhadap kemampuan membaca anak $(\beta=0.227 ; \mathrm{t}=2.431)$.

\section{Pembahasan}

Data empiris menunjukkan bahwa secara umum tanda-tanda kesiapan membaca sudah muncul pada anak TK dengan tingkatan sedang. Oleh karena itu, sangat tepat langkah para guru TK di Kabupaten Sidoarjo yang rata-rata telah mengenalkan kegiatan baca-tulis kepada anak TK. Temuan di atas memperkuat pendapat yang dikemukakan oleh Teale dan Sulzby serta hasil penelitian Chandler yang dilakukan tahun 2000. Teale dan Sulzby dalam Fisher (1998: 8) mengatakan bahwa kesiapan membaca digunakan untuk menggambarkan perkembangan literasi pada anak kecil, sebelum berusia 5 atau 6 tahun, ketika mereka mulai membaca dan menulis. Kesiapan membaca dipengaruhi oleh budaya baca keluarga, ketersediaan bahan bacaan untuk anak di rumah, dan kegiatan literasi 
keluarga bersama anak. Hal ini berarti kesiapan membaca anak TK bervariasi, anak yang berasal dari lingkungan keluarga yang mendukung atau kondusif. (mempunyai budaya baca tinggi, disediakan bahan bacaan yang cukup, dan melakukan kegiatan literasi bersama anak yang tinggi) kesiapan membaca anak akan muncul lebih awal dibandingkan dengan anak yang berasal dari keluarga yang mempunyai lingkungan tidak mendukung.

Hasil analisis menunjukkan bahwa kesiapan membaca mempunyai pengaruh signifikan terhadap aktivitas anak dalam kegiatan belajar membaca di TK dan kemampuan membaca anak. Hal ini berarti kegiatan belajar membaca di TK sebaiknya hanya diberikan kepada anak yang sudah mempunyai kesiapan membaca. Pelaksanaan kegiatan 'belajar membaca yang diberikan kepada anak yang belum mempunyai kesiapan membaca tidak akan memperoleh hasil yang optimal. Temuan ini sejalan dengan pendapat Peaget yang menyatakan bahwa perkembangan kognitif anak secara internal mendahului kemampuan berpikir atau belajarnya. Dalam hal ini tugas pendidik adalah mengamati munculnya kesiapan pada diri anak dan memberi rangsangan atau latihan sesuai dengan tingkat perkembangannya.

Pengaruh kegiatan literasi keluarga bersama anak terhadap aktivitas anak dalam kegiatan belajar membaca dan kemampuan membaca terbukti tidak signifikan. Hasil ini kemungkinan disebabkan hal-hal berikut.

a. Besarnya pengaruh sekolah terhadap aktivitas anak dalam kegiatan belajar membaca dan kemampuan membaca anak.

b. Pelaksanaan kegiatan literasi keluarga bersama anak kurang sesuai dengan prinsip-prinsip belajar anak TK sehingga hasilnya tidak atau kurang optimal.

c. Cakupan kegiatan literasi keluarga bersama anak yang diungkapkan dalam penelitian ini hanya kegiatan literasi yang dilakukan keluarga terutama orang tua bersama anak. Kenyataan di lapangan menunjukkan banyak anak TK yang mengikuti kegiatan literasi dengan bimbingan guru atau pembimbing belajar yang lain dan dilaksanakan di luar jam kegiatan belajar di TK. 
Secara keseluruhan hasil analisis yang telah diuraikan di atas disajikan pada Diagram 1.

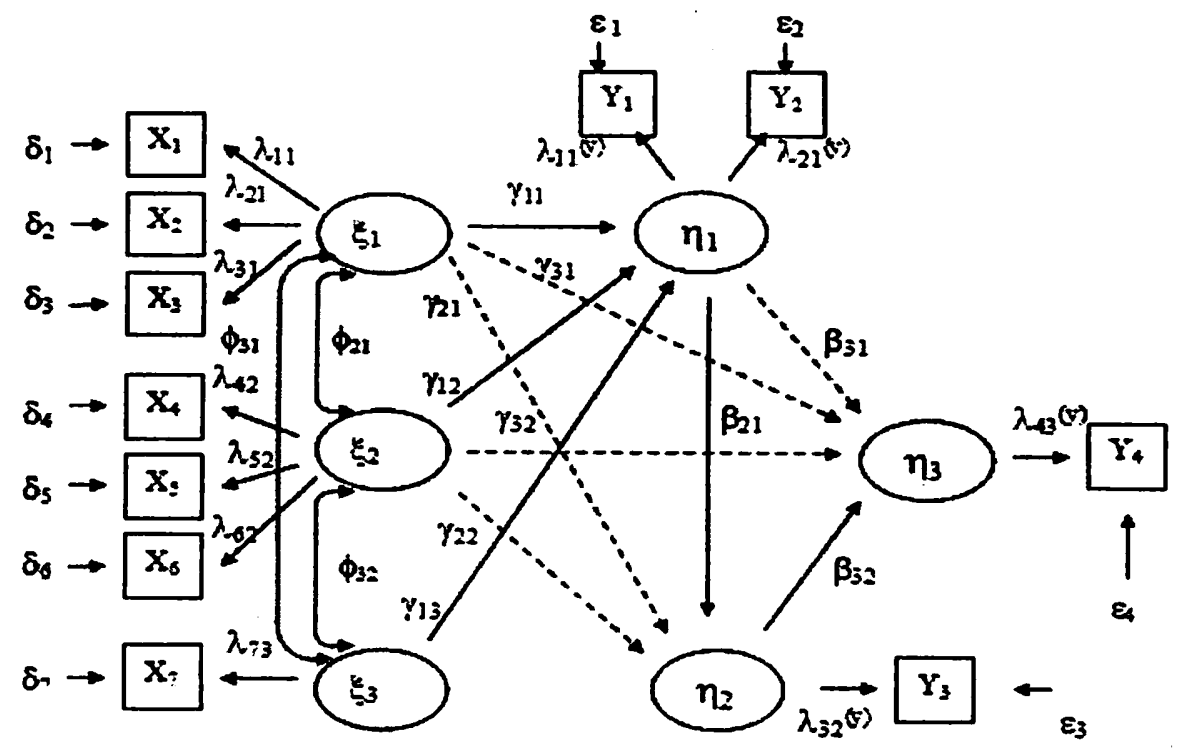

Diagram 1. Bentuk Hubungan Antarvariabel Model Evaluasi Kebijakan Kegiatan Belajar Membaca di TK*

\section{Keterangan:}

* = Didasarkan pada pengaruh keseluruhan yang signifikan

$\mathrm{X}_{1} \quad=$ Kebiasaan Membaca Ayah

$\mathrm{X}_{2} \quad=$ Kebiasaan Membaca Ibu

$\mathrm{X}_{3}=$ Kebiasaan Membaca Anak

$\mathrm{X}_{4} \quad=$ Jenis Bahan Bacaan yang Tersedia

$\mathrm{X}_{5} \quad=$ Jumlah Bahan Bacaan yang Tersedia

$\mathrm{x}_{6}=$ Jumlah Bahan Bacaan yang Dibeli 3 Bulan Terakhir

$\mathrm{X}_{7} \quad=$ Kegiatan Literasi Keluarga Bersama Anak

$\xi_{1} \quad=$ Budaya Baca Keluarga

$\xi_{2} \quad=$ Ketersediaan Bahan Bacaan untuk Anak di Rumah

$\xi_{3}=$ Kegiatan Literasi Keluarga Bersama Anak

$\mathrm{Y}_{1} \quad=$ Tanda Kesiapan Membaca Berkaitan dengan Perilaku 
$\mathrm{Y}_{2} \quad=$ Tanda Kesiapan Membaca Berkaitan dg Kemampuan

$\mathrm{Y}_{3}=$ Aktivitas Anak dalam Kegiatan Belajar Membaca di TK

$Y_{4}=$ Kemampuan Membaca Anak

$\eta_{1}=$ Kesiapan Membaca Anak

$\eta_{2} \quad=$ Aktivitas Anak dalam Kegiatan Belajar Membaca

$\eta_{3}=$ Kemampuan Membaca Anak

$\longrightarrow=$ Pengaruh keseluruhan sekaligus langsung

$\ldots=$ Pengaruh keseluruhan

\section{Simpulan}

Model evaluasi $\mathrm{KMPH}$ terbukti didukung data $\left(\chi^{2}=28,20 ; \mathrm{p}=\right.$ 0.659; $G F I=0,992)$. Hubungan antarvariabel dalam model evaluasi KMPH sebagai berikut.

1. Budaya baca keluarga $(\gamma=0.428, \mathrm{t}=3.727)$, ketersediaan bahan bacaan untuk anak di rumah $(\gamma=0.436, t=3.198)$, dan kegiatan literasi keluarga bersama anak $(\gamma=0.078, t=2.382)$ mempunyai pengaruh keseluruhan sekaligus pengaruh langsung yang signifikan terhadap kesiapan membaca anak.

2. Budaya baca keluarga $(\gamma=0.546, \mathrm{t}=3.372)$ dan ketersediaan bahan bacaan untuk anak di rumah $(\gamma=0.499, \mathrm{t}=2.911)$ mempunyai pengaruh keseluruhan yang signifikan terhadap aktivitas anak dalam kegiatan belajar membaca di TK, sedangkan pengaruh keseluruhan kegiatan literasi keluarga bersama anak terhadap aktivitas anak dalam kegiatan belajar membaca di TK terbukti tidak signifikan. Pengaruh langsung ketiga variabel tersebut terhadap aktivitas anak dalam kegiatan belajar membaca di TK terbukti tidak signifikan.

3. Budaya baca keluarga $(\gamma=0.436, \mathrm{t}=2.655 ; \gamma=0.780, \mathrm{t}=2.147)$ dan ketersediaan bahan bacaan untuk anak di rumah $(\gamma=0.535, \mathrm{t}=3.033$; $\gamma=0.707, \mathrm{t}=2.074)$ mempunyai pengaruh keseluruhan dan pengaruh tidak langsung yang signifikan terhadap kemampuan membaca anak, sedangkan pengaruh langsung kedua variabel tersebut terhadap 
kemampuan membaca anak terbukti tidak signifikan. Sebaliknya, pengaruh keseluruhan maupun langsung kegiatan literasi keluarga bersama anak terhadap kemampuan membaca anak terbukti tidak signifikan.

4. Kesiapan membaca anak mempunyai pengaruh keseluruhan sekaligus pengaruh langsung yang signifikan terhadap aktivitas anak dalam kegiatan belajar membaca di TK $(\beta=1.126, t=2.114)$. Pengaruh langsung kesiapan membaca terhadap kemampuan membaca anak terbukti tidak signifikan. Namun, pengaruh keseluruhan dan pengaruh tidak langsung kesiapan membaca terhadap kemampuan membaca terbukti signifikan $(\beta=1.617, \mathrm{t}=2.270 ; \beta=0.256, \mathrm{t}=2.270)$

5. Aktivitas anak dalam kegiatan belajar membaca di TK mempunyai pengaruh keseluruhan sekaligus pengaruh langsung yang signifikan terhadap kemampuan membaca anak $(\beta=0.227 ; \mathrm{t}=2.431)$.

Berdasarkan bentuk hubungan di atas dapat disimpulkan bahwa kesiapan membaca merupakan faktor utama (sentral) dalam model evaluasi KMPH. Kesiapan membaca merupakan faktor internal yang menunjukkan kematangan potensial pada diri anak. Kematangan ini dipengaruhi oleh faktor eksternal, yaitu: budaya baca keluarga, ketersediaan bahan bacaan untuk anak di rumah, dan kegiatan literasi keluarga bersama anak. Hasil analisis juga menunjukkan bahwa kesiapan membaca berpengaruh terhadap aktivitas anak dalam kegiatan belajar membaca dan kemampuan membaca. Namun, pengaruh kesiapan membaca terhadap kemampuan membaca melalui aktivitas anak dalam kegiatan belajar membaca. Hal ini berarti anak yang telah mempunyai kesiapan membaca memerlukan rangsangan atau bimbingan agar dapat mengaktualisasikan potensi yang dimiliki menjadi kemampuan membaca.

Implikasi hasil penelitian ini adalah anak yang berasal dari lingkungan keluarga yang kondusif (keluarga yang mempunyai budaya baca tinggi, menyediakan bahan bacaan yang cukup untuk anak di rumah, dan melakukan kegiatan literasi bersama anak) kesiapan membacanya muncul lebih awal dibandingkan dengan anak yang berasal dari lingkungan keluarga yang tidak kondusif. Oleh karena itu, kebijakan Departemen Pendidikan 
Nasional, baik tingkat nasional maupun daerah, hendaknya memberi otonomi kepada guru untuk memberikan atau tidak memberikan kegiatan belajar membaca sesuai dengan tingkat kesiapan membaca anak.

Anak TK di Kabupaten Sidoarjo menunjukkan bahwa mereka telah memiliki kesiapan membaca sehingga sudah siap mengikuti kegiatan belajar membaca awal. Pelaksanaan kegiatan belajar membaca di TK hendaknya memperhatikan kesiapan membaca masing-masing anak. Oleh karena itu, pendekatan yang digunakan hendaknya bersifat kelompok atau individual.

\section{Daftar Pustaka}

Bodrova, E., Leong, D. J., \& Paynter, D. E. (Oktober 1999). Literacy standard for preschool learners. Educational Leadership. Volume 57, number 2 Oktober 1999. Diambil pada tanggal 20 Nopember 2001, dari http://www.ascd.org/readingroom/edlead/9910/bodrova.html.

Chandler, K., West, J., \& Hausken, E. (24 Oktober 1995). Approaching kindergarten: a look at preschools in US. National Center for Education Statistics. Diambil pada tanggal 27 September 2002, dari http://nces.ed.gov/pubsearch/pubsinfo.asp?pubid=95280.

Denton, K. \& West, J. (20 Maret 2002). Children's reading and mathematics achievement in kindergarten and first grade. Education Statistics Quarterly. Diambil pada tanggal 5 Nopember 2001, dari http://nces.ed.gov/pubs2002/quarterly/spring/Q3-1.asp.

Departemen Pendidikan Nasional (2000). Permainan membaca dan menulis di Taman Kanak-Kanak. Jakarta: Proyek Peningkatan Mutu Taman Kanak-Kanak.

Departemen Pendidikan Nasional (2004). Kurikulum 2004, standar kompetensi Taman Kanak-Kanak dan Raudatul Athfal. Jakarta: Direktorat Pendidikan TK dan SD.

Fisher, B. (1998). Joyful learning in kindergarten. Portsmouth: A Division of Reed Elsevier Inc. 
Pengembangan Model Evaluasi Kebijakan Kogiatan Belajor Membaca di Taman Kanak-Kanak

Gillet, J. W. \& Temple, C. (1994). Understanding reading problem: Assessment and instruction. New York: Harper Collins College Publishers.

Heilman, A.W., Blair, T. R., \& Rupley, W. H. (1986). Principles and practices of teaching reading. Columbus: Charles E. Merrill Publishing Company.

Hurlock (1978). Child development. Singapore: McGraw-Hill International Book Company.

La Paro, K. M., \& Pianta, R. C. (2000). Predicting children's competence in the early school years: Meta Analytic Review. Review of Educational Research. Volume 70, No. 4, pp. 443 - 484.

Masyhor Almutahar (1997). Sekolah sebagai pusat pengembangan minat dan kegemaran membaca. Laporan lokakarya pengembangan minat dan kegemaran membaca siswa, buku 3 (pp. 9 - 14). Jakarta: Departemen Pendidikan dan Kebudayaan.

Mountain, L. (1981). Early reading instruction, bow to teach reading before first grade. Rhode Island: Jamestown Publishers.

Nord, CW., Lennon, J., Liu, B., \& Chandler, K. (31 Januari 2000). Home literacy activities and signs of children's emerging literacy 1993 and 1999. National Center for Education Statistics. Diambil pada tanggal 13 Nopember 2001, dari http://nces.ed.gov/pubsearch/pubsinfo.asp? pubid $=2000026$.

Ramsburg, D. (1998). Understanding literacy development in young children. Parent News Archives April 1998. Diambil pada tanggal 21 Nopember 2001, dari http://npin.org/pnews/1998/pnew498/ pnew498b.html.

Slavin, R. E. (1994). Educational psychology: Theory into practice. Boston: Allyn and Bacon.

White, S., \& Dewitz, P. (1996). Reading proficiency and home support for literacy. National Center for Education Statistics. Diambil pada tanggal 24 Nopember 2001, dari http://nces.ed.gov/pubs96/web/96814.asp. 